\title{
Kütləvi media resurslarında fərdi məlumatların mühafizəsi problemləri
}

\author{
Sünbül Zalova \\ AMEA İnformasiya Texnologiyaları İnstitutu, Bak1, Azərbaycan \\ sunbulzalova@gmail.com
}

\begin{abstract}
Xülasə - Bu məqalədə fərdi məlumat, fərdi məlumatın növləri, kütləvi media resurslarında fərdi məlumatların mühafizəsi problemləri araşdırılmışdır. Bu istiqamətdə olan qanunlar, dünya və Azərbaycan təcrübəsi analiz edilmişdir. Problemlərin həlli istiqamətində bir sıra təkliflər irəli sürülmüșdür.
\end{abstract}

Açar sözlor-fordi məlumatlar; şoxsi həyat; həssas məlumatlar, sosial media, kütlovi media resurslart

\section{GIRISS}

Bugün texnologiyanın sürətli inkafi ilə əlaqədar fərdi məlumatların mühafizəsi getdikcə çətinləşir. Yeni texnoloji yeniliklərin pilotsuz uçuş aparatları, robotexnikalar, süni intellekt və s. meydana gəlməsi şəxsi məlumatların yayılmasını və başqaları tərəfindən ələ keçirilməsini asanlaşdırır. "Facebook","Twitter", "Instgram" və s. sosial media saytlarının istifadəçiləri öz fikir və düşüncələrini əks etdirməklə yanaşı, fotoşəkil, video və şəxsi mesajlarını hər kəsin görə biləcəyi şəkildə paylaşırlar. Bundan başqa internet saytları istifadəçilərinin ünvan, telefon, əvvəl baxdığı vebsəhifələr kimi şəxsi məlumatlarını saxlayır, istifadəçi profili yaradırlar. $\mathrm{Bu}$ da həmin məlumatların daha sonra başqalarının əlinə keçməsinə şərait yaradır. Fərdi məlumatların istifadəsi ilə bağlı hüquqi məhdudiyyətlərin olmasına baxmayaraq fərdi məlumatlardan qeyri qanuni istifadə, bu sahənin "qara bazarının" formalaşmasına şərait yaradır.

\section{FӘRDİ MӘLUMATLARIN TəSNIFFATI HAQQINDA}

Fərdi məlumatlar şəxsi həyatın ayrılmaz tərkib hissəsidir. Hər hansı bir şəxsin fərdi məlumatlarının qorunması, başqa bir şəxs tərəfindən əlçatan olmamasını istəmək hüququ var və bu qanunla tənzimlənir.

Hər bir şəxsin fərdi məlumatlarını 3 istiqamətə bölmək olar[1].

1. Açıq məlumatlar

2. Şəxsi məlumatlar

3. Gizli məlumatlar

Açıq məlumatlar - şəxsin bu məlumatları hər kəsin bildiyindən narahat olmadığı məlumatlardır. (Məs: ad, soyad, vəzifə və s.)
Şəxsi məlumatlar - Şəxsin hər kəsin bilməsini istəmədiyi, yalnız ailə və yaxınlarının bildiyi məlumatlardır.

Gizli məlumatlar - 3-cü şəxs tərəfindən bilinməsi istənməyən məlumatlardır.

Hər kəsə açıq olan məlumatlardan başqa şəxsi və gizli bilgilərin şəxsin icazəsi olmadan ələ keçirilməsi, saxlanılması və yayılması şəxsiyyət hüququnun pozulmasıdır [1].

Fərdi məlumatlar termininin başa düşülməsi üçün bir sıra izahatların verilməsi tələb olunur. Avropa İttifaq1 qanunvericiliyində, eləcə də Avropa Şurasının hüquqi sənədlərində « fərdi məlumatlar » termininin tərifi aşağıdakı şəkildə müəyyən edilmişdir:

- "kimliyi müəyyən edilə bilən fiziki şəxs barəsində məlumat, yəni, kimliyi bariz şəkildə aşkar olan və ya əlavə məlumatların əldə edilməsi vasitəsilə müəyyən edilə bilən şəxsə dair məlumatlar"

Səxsə aid olan istənilən məlumat fərdi məlumat kimi təsfir edilə bilər. Yəni fərdi məlumatlar şəxsin şəxsi həyatına və ya peşə və ictimai həyatına aid olan məlumatları əhatə edir. Fərdi məlumatların hansı şəkildə saxlanması və ya istifadə edilməsinin məlumatların mühafizəsinə dair qanunvericiliyin tətbiq edilməsi ilə heç bir əlaqəsi yoxdur. Yazılı və ya şifahi ifadələr, eləcə də şəkillər fərdi məlumatlar daşıya bilər. Şəxsin DNT məlumatlarını daşıdığına görə insan toxumalarının hüceyrə nümunələri də fərdi məlumat hesab edilə bilər. Həm Avropa İttifaqı qanunvericiliyində, həm də Avropa Şurasının qanunvericiliyində xususi kateqoriyaya daxil olan spesifik məlumatlar nəzərdə tutulmuşdur ki həmin məlumatlar işlənildikləri zaman öz təbiətlərinə görə aidiyyatı olan şəxslər üçün risk törədə bilərlər, buna görə də, onların geniş şəkildə mühafizə olunmasına ehtiyac vardır. Xususi kateqoriyaya daxil edilən bu spesifik məlumatların (həssas məlumatlar adlandırılır) işlənməsi yalnız səlahiyyətli qurumlar tərəfindən xüsusi təminatlara əməl edilməklə yerinə yetirilməlidir. Həssas məlumatların tərifinə gəldikdə, 108 saylı Konvensiya (6-c1 maddə) və Məlumatların Mühafizəsinə dair Direktiv (8-ci Maddə) aşağıdakı kateqoriyaları nəzərdə tutur[2].

1. İrqi və ya etnik mənşəyi aşkarlayan fərdi məlumatlar;

2. Siyasi, dini və ya digər əqidəni aşkar edən fərdi məlumatlar; 


\section{“Informasiya tohlükosizliyinin aktual multidissiplinar elmi-praktiki problemlori” V respublika konfransı, 29 noyabr 2019-cu il}

\section{Sağlamlıq və ya cinsi həyata dair fərdi məlumatlar.}

Məlumatların Mühafizəsinə dair Direktiv (Aİ-nın məlumatların mühafizəsinə dair əsas sənədi Avropa Parlamentinin və Avropa İttifaq1 Şurasının 95/46/EC saylı 24 oktyabr 1995-ci il tarixli, fiziki şəxslərə aid olan fərdi məlumatların işlənilməsi və həmin məlumatların sərbəst dövriyyəsinə dair Direktivdir). həmkarlar ittifaqına üzvlüyü də həssas məlumatlar siyahısına daxil edir, çünki, bu məlumat şəxsin siyasi dünyagörüşü və mənsubiyyətini aşkar şəkildə bəyan edir. Bundan əlavə, 108 saylı Konvensiya cinayət işi ilə bağlı məhkumluğa dair fərdi məlumatları da həssas məlumat kimi qiymətləndirir [2].

Avropa Parlamenti və Avropa Şurasının 27 aprel 2016-cı il qərarı ilə Ümumi Məlumatların Qorunması Tənzimlənməsi (GDPR General Data Protection Regulation) haqqinda qaydalar qəbul olunub. Bu qaydalara əsasən fərdi məlumatları işlədən tərəflər məlumatların qorunması prinsiplərini həyata keçirmək üçün zəruri texniki və institusional tədbirlər görməlidirlər. Fərdi məlumatların idarə olunduğu iş prosesləri, məlumatların qorunması prinsiplərinə uyğun olaraq hazırlanmalı və aparılmalı, məlumatların qorunması üçün tədbirlər görülməlidir. Fərdi məlumat sahibindən açıq razılıq alınmadıqda heç bir şəxsi məlumat işlənə bilməz. Müvafiq şəxs istənilən vaxt bu icazəni ləğv etmək hüququna malikdir. Qaydalara görə fərdi məlumat operatorları məlumatların emalının məqsədini, qanuni əsaslarını, məlumatların nə qədər saxlanıldığını və hər hansı bir üçüncü tərəflə və ya Avropa İqtisadi Bölgəsindən kənarda hər hans1 bir yerdə bölüşdürülməməsi barədə dəqiq məlumat verməlidirlər. Şəxsi məlumat sahibləri istənilən vaxt saxlanılan məlumatların surətini tələb etmək və müəyyən şərtlərdə silmək hüququna malikdirlər. Müəssisələr istifadəçi məxfiliyinə mənfi təsir göstərən istənilən məlumat pozuntusu (məs., məlumatın oğurlanmas1) barədə 72 saat ərzində istifadəçilərə məlumat verməlidirlər. Oks təqdirdə qaydaların pozulduğu aşkar edilən şirkətlər 20 milyon avroya qədər və ya şirkətin illik gəlirinin 4 faizi qədər cərimə edilə bilər [3].

\section{FORDİ MOLUMATLARIN HÜQUQİ TONZIMLONMӘSİ}

Heç bir qanunvericilik aktında fərdi məlumatların dəqiq siyahıs1 və ya sərhədi müəyyən olunmayıb. Azərbaycan qanunvericiliyinə görə, "fərdi məlumatlar - şəxsin kimliyini birbaşa və ya dolayısı ilə müəyyənləşdirməyə imkan verən istənilən məlumatlardır". "Fordi məlumatlar haqqında" Azərbaycan Respublikasının Qanunun əsas məqsədi fərdi məlumatların toplanılmasının, işlənilməsinin və mühafizəsinin qanunvericilik əsaslarını və ümumi prinsiplərini, həmin sahədə dövlət tənzimləməsinin qayda və tələblərini, fərdi məlumatların informasiya ehtiyatlarında formalaşdırılması, informasiya sistemlərinin yaradılması, informasiyanın verilməsi və ötürülməsi qaydalarını, bu prosesdə iştirak edən şəxslərin hüquqlarını, vəzifələrini və məsuliyyətinin əsaslarını müəyyən etməkdən, əsas insan və vətəndaş hüquqlarını və azadlıqlarını, o cümlədən şəxsi və ailə həyatının sirrini saxlamaq hüququnu müdafiə etməkdən ibarətdir[4]. 2009-cu ildə Azərbaycan
Respublikası "Fərdi məlumatların avtomatlaşdırılmış qaydada işlənməsi ilə əlaqədar şəxslərin qorunması haqqında"Avropa Şurası Konvensiyasına qoşulmuşdur[5].

Azərbaycan Respublikasının Konstitusiyasının 50-ci maddəsinə əsasən hər bir şəxsin məlumat azadlığı vardır[6].

- Hər kəsin istədiyi məlumatı qanuni yolla axtarmaq, əldə etmək, ötürmək, hazırlamaq və yaymaq azadlığı vardir.

- Kütləvi informasiyanın azadlığına təminat verilir. Kütləvi informasiya vasitələrində, o cümlədən mətbuatda dövlət senzurası qadağandır.

- Hər kəsin kütləvi informasiya vasitələrində dərc edilən və onun hüquqlarını pozan və ya mənafelərinə xələl gətirən məlumatı təkzib etmək və ya ona cavab vermək hüququna təminat verilir.

Təəssüf ki, hazırda bir çox mətbuat nümayəndələri bu qanundan sui-istifadə edərək şəxslərin fərdi məlumatlarını yayır və şəxsi məlumatların toxunulmazlığına xələl gətirirlər. Fərdi məlumatların bir çox qanunlarla tənzimlənməsinə baxmayaraq, bu sahədə müəyyən boşluqlar vardır. Qanunlara ciddi əməl olunmur. Bəzi televiziya kanalları və mətbuat orqanları reytinq xətrinə və ya sifariş əsasında jurnalistin etik davranışlarından kənara çıxırlar. Hazırda media sahəsində və toy şənliklərinin çəkilişində dronlardan istifadə edilir. Pilotsuz uçan aparatların istifadəsini tənzimləyən qanun və ya qaydalar olmasa da, Cinayət Məcəlləsininin 156-c1 maddəsində şəxsi həyatın pozulması maddəsində dronlardan istifadəyə görə məsuliyyət nəzərdə tutulub[7]. Qanuna görə şəxsi və ailə həyatının sirri olan video və foto çəkilişi materiallarının, səs yazılarının məsafədən idarə edilən pilotsuz uçan aparatlardan istifadə etməklə yayılması cinayət məsuliyyəti yaradır. Bu hal baş verdikdə təqsirləndirilən şəxs iki ilədək müddətə azadlıqdan məhrum etmə ilə cəzalandırıla bilər. Onlayn medianın hüquqi tənzimlənməsində olan problemlər fərdi məlumatların internet mühütündə təhlükəsizliyinə zəmanət verə bilmir. Azərbaycan qanunvericiliyində 2017-ci ildə edilmiş əlavə və dəyişikliklər internet mühitində fərdi məlumatların qanunsuz dövriyyəsinin qarşısının alınmasına xidmət edir. Lakin bu məsələ ilə bağlı ölkəmizdə məhkəmə praktikası çox zəifdir, hüquqları pozulan şəxslər çox nadir hallarda məhkəmələrə müraciət edirlər.

\section{FӘRDİ MӘLUMATLAR VӘ KÜTLӘVİ MEDİA RESURSLARI}

Fərdi məlumatların qeyri qanuni yollarla yayılmasında elektron Kütləvi İnformasiya Vasitələri (KIV) və sosial şəbəkə istifadəçiləri xüsusi rol oynayırlar. KIV-də vətəndaşların fərdi məlumatlarının qanunsuz açıqlanmasının neqativ nəticələri ilə əlaqədar xəbərlərə tez-tez rast gəlmək mümkündür. Təəssüf ki, bu kimi hallarla bağlı tədqiqatlar aparılmır və statistik hesabatlar hazırlanmır[8]. Jurnalistlərin fərdi məlumatlarla işləyərkən müvafiq hüquqi tələbləri yaxşı bilməmələri və nəzərə almamaları bu cür halların kütləviləşməsinə səbəb olur. Mediada şəxsi həyata dair yanlış məlumatlar bir sıra hallarda müəyyən şəxsləri nüfuzdan salmaq, karyerasına zərbə vurmaq 


\section{"Informasiya təhlükasizliyinin aktual multidissiplinar elmi-praktiki problemlori” V respublika konfransi, 29 noyabr 2019-cu il}

və s. kimi neqativ məqsədlərlə yayılır. Texnologiyanın sürətli inkişafı nəticəsində dezinformasiya xarakterli montaj edilmiş audio, video, foto materialları yaymaq getdikcə sadələşir və kütləvi hal alır. $\mathrm{Bu}$ da göstərir ki, şəxsi həyatın toxunulmazlığının təmin olunması, fərdi məlumatların qorunması məsələləri müasir dövrdə informasiya texnologiyalarının inkişafı ilə bağlı olaraq çətinləşmişdir. İnternet xəbər istehsalçılarının bilərəkdən və ya bilməyərəkdən "Xüsusi kateqoriyalı fərdi məlumatların şəxsi həyat"1n qorunması prinsipini intensiv şəkildə pozmaları, ümumiyyətlə, "Fordi məlumatların qorunması" qanununa laqeyd yanaşmaları müşahidə olunur.

Azərbaycan Mətbuat Şurasının 2019-cu il üçün açıqladığı illik hesabatdan aydın olur ki, Şuraya il ərzində ünvanlanmış şikayətlərin bir qismi də məhz şəxsi həyat sirrinin onlayn mediada pozulmasına aiddir[9]. "İnternet və xüsusi kateqoriyalı fərdi məlumatlar-şəxsi həyat" mövzusunda 25 iyun 2019-cu il tarixində Bakıda konfrans, Mingəçevir və Astarada isə bu mövzuda seminar keçirilib. Konfransda QHT rəhbərləri, media və ictimaiyyət nümayəndələri iştirak ediblər. Konfransın əsas məqsədinin həm qlobal, həm də lokal səviyyədə ortaya çıxan fərdi məlumatların mühafizəsinə dair problemlərin aradan qaldırılmasına yardım göstərmək olduğu deyilib. Mətbuatda fərdi məlumatların icazəsiz olaraq yayımlanmasında anonim mənbələrində rolu böyükdür. Etibarsiz mənbələrə istinad edilərək hər hansı bir şəxs haqqında verilən fərdi məlumatlar həm KIV -nə, həm də həmin şəxsə problemlər yaradir.

\section{NӘTİCə}

Nəticə olaraq jurnalistlər informasiya hazırlayarkən etik dəyərlərini unutmamalı, hər kəsin fərdi həyatına hörmətlə yanaşmalıdır. Fərdi məlumatların mühafizəsinə dair qanunlar daha da gücləndirilməlidir. Reket jurnalistikasının inkişafına şərait yaranmamalıdır. Fərdi məlumatların yayılmasına icazə yalnız çox vacib situasiyalarda verilməlidir. Məsələn, hər hansı bir cinayətkar barədə məlumat yayılmasına zərurət yarandıqda fərdi məlumatların mühafizəsinə dair qanunlar pozula bilər. Oks təqdirdə belə halların baş verməsi qəbul edilməzdir.

\section{İSTINADLAR}

[1] A. Kemal, "Kişilik hakki kapsaminda sosyal medyada kişisel verilerin korunmasi ve veri sahibinin rizası", pp. $270-300$.

[2] Avropada fərdi məlumatların mühafizəsi, pp.26, http://academy-justice.gov.az.

[3] Data protection, https://ec.europa.eu/info/law/law-topic/data-protection_en.

[4] Fordi məlumatlar haqqında Azərbaycan Respublikasının Qanunu http://www.e-qanun.az

[5] "Fərdi məlumatların avtomatlașdırılmış qaydada işlənməsi ilə əlaqədar şəxslərin qorunması haqqında" konvensiyanın təsdiq edilməsi barədə Azərbaycan Respublikasinin Qanunu,

http://www.e-qanun.az/framework/18625

[6] Azərbaycan Respublikasinin Konstitusiyasi, http://www.e-qanun.az/framework/897.

[7] Azərbaycan Respublikasinin Mülki Məcəlləsi, http://www.e-qanun.az/code/8.

[8] Azərbaycan Respublikasinin Cinayət Məcəlləsi, http://www.e-qanun.az/code/11.

[9] Oliquliyev R.M.,. Mahmudov R.Ş "Milli mentalitet kontekstində fərdi məlumatların həssaslı̆̆ı və onların təhlükəsizliyinin təmin olunması məsələləri" İnformasiya cəmiyyəti problemləri, 2019. vol 2, pp 117-128.

[10] http://www.presscouncil.az/az/news/114.

\section{ISSUES OF PERSONAL DATA PROTECTION IN MASS MEDIA RESOURCES}

Sunbul Zalova

Institute of Information Technology of ANAS, Baku, Azerbaijan

$$
\text { sunbulzalova@gmail.com }
$$

Abstract - Personal data, the types of personal data and the issues of personal data protection in mass media resources are explored in this article. Laws in this area, the international experience, as well as experience in Azerbaijan are shown. A number of proposals for the solution of the problem are identified.

Keywords - personal data, personal life, sensitive information, social media, mass media resources 